\title{
EL VIRUS O’NYONG-NYONG EN LATINOAMÉRICA: ¿UN RIESGO IGNORADO?
}

\author{
THE O'NYONG-NYONG VIRUS IN LATIN AMERICA: AN IGNORED RISK?
}

\section{Carlos Miguel RIOS-GONZÁLEZ , Ginno Alessandro DE BENEDICTIS-SERRANO².}

\footnotetext{
${ }^{1}$ Facultad de Ciencias Médicas, Universidad Nacional de Caaguazú, Coronel Oviedo - Paraguay.
}

${ }^{2}$ Facultad de Ciencias de la Salud, Universidad de Carabobo Sede Aragua, Aragua - Venezuela.

Cómo citar este artículo: Ríos-González CM, De Benedictis-Serrano GA. El virus O’nyong-nyong en Latinoamérica: ¿un riesgo ignorado? Medicina Clínica y Social. 2017;1(3):222-223.

\section{Estimado Editor,}

Ante todo, nuestras sinceras felicitaciones por la labor que viene desarrollando frente a su distinguida Revista y, a la vez, mediante esta misiva nos gustaría traer a discusión la importancia que tiene el virus O'nyong-nyong (ONNV) como posible riesgo para la salud de la población latinoamericana.

Es imperioso rememorar que este virus, perteneciente a la familia Togaviridae, es sumamente semejante al Chikungunya (CHIKV) (1), recordando que los Alphavirus que causan artritis en humanos son una emergencia global, debido a que pueden imposibilitar o dificultar la vida diaria de quien los padece (2). El ONNV es ignorado en Latinoamérica, ya que es considerado un virus del continente africano y, además, con investigaciones relativamente escasas (3).

En Europa ya se ha observado un caso importado, el cual tuvo un diagnóstico cruzado con CHIKV, sin ninguna complicación (4); no obstante, como toda arbovirosis, al tener un vector apto, bastará con el viaje de una persona del continente africano al nuestro para diseminarse, ya que en Latinoamérica se cumplen las condiciones para su desarrollo y diseminación, lo cual puede apreciarse por la amplia distribución vectorial y las enfermedades reemergentes del continente.

En afirmación a tal problema se han realizado investigaciones in vitro e in vivo, las cuales han demostrado el potencial de infección que tiene el ONNV y las características que posee el Aedes aegypti como posible transmisor de la enfermedad $(5,6)$. El Aedes aegypti es uno de los principales transmisores de arbovirosis debido a su alta capacidad de adaptación y su amplia distribución en América. A lo anterior se suma la ausencia de herramientas eficaces para vigilar dicho vector y poder determinar medidas de control que funcionen de manera permanente $(7,8)$. Lo mencionado es importante en el reconocimiento del peligro que representa el ONNV y su relación con el posible vector, que se encuentra distribuido en casi todos los países latinoamericanos.

Con base en todo lo anterior, nuestra preocupación se centra en el poco interés sobre esta enfermedad y su medio de transmisión, siendo uno de los posibles virus emergentes en Latinoamérica. Consideramos importante incentivar la investigación y la preparación académica de todos los profesionales del área de la salud ante tal amenaza latente, aunque aún ignorada. 


\section{CONFLICTOS DE INTERÉS Y FUENTE DE FINANCIACIÓN}

Los autores declaran no poseer conflictos de interés. Fuente de financiación: ninguna.

\section{REFERENCIAS BIBLIOGRÁFICAS}

1. Rios-González CM. O’nyong-nyong virus: next arbovirus in Latin America?. J Infect Public Health. Forthcoming 2017. https://doi.org/10.1016/j.jiph.2016.11.020

2. Lwande OW, Obanda V, Bucht G, Mosomtai G, Otieno V, Ahlm C, et al. Global emergence of Alphaviruses that cause arthritis in humans. Infection Ecology and Epidemiology. 2015;5(1):29853. https://doi.org/10.3402/iee.v5.29853

3. Rios-González CM. Bibliometric study of international scientific production in O'nyongnyong virus during the years 1962-2016. J Infect Public Health. 2017;10(1):137-138. https://.doi.org/10.1016/i.jiph.2016.05.006

4. Tappe D, Kapaun A, Emmerich P, Campos R, Cadar D, Günther S, et al. O'nyong-nyong Virus Infection Imported to Europe from Kenya by a traveler. Emerg Infect Dis. 2014 Oct; 20(10): 1766-1767. https://doi.org/10.3201/eid2010.140823

5. Vanlandingham DL, Hong C, Klingler K, Tsetsarkin K, McElroy KL, Powers AM, et al. Differential infectivities of o'nyong-nyong and chikungunya virus isolates in Anopheles gambiae and Aedes aegypti mosquitoes. Am J Trop Med Hyg. 2005;72(5):616-621. URL.

6. Vanlandingham DL, Tsetsarkin K, Klingler KA, Hong C, McElroy KL, Lehane MJ, et al. Determinants of vector specificity of o'nyong nyong and chikungunya viruses in Anopheles and Aedes mosquitoes. Am. J. Trop. Med. Hyg. 2006;74(4):663-669. URL.

7. Barrera R. Recomendaciones para la vigilancia de Aedes aegypti. Biomédica. 2016;36(3):454-462. https://doi.org/10.7705/biomedica.v36i3.2892

8. Rey JR, Lounibos P. Ecología de Aedes aegypti y Aedes albopictus en América y transmisión de enfermedades. Biomédica. 2015;35(2):177-185. https://doi.org/10.7705/biomedica.v35i2.2514 